\title{
KAJIAN VARIASI SEKUNES INTRASPESIES DAN FILOGENETIK MONYET HITAM SULAWESI (Macaca nigra) DENGAN MENGGUNAKAN GEN COI
}

\author{
Fitri E. Hasibuan $^{1)}$, Feky R. Mantiri ${ }^{1)}$, Rooije R.H. Rumende ${ }^{1)}$ \\ ${ }^{1)}$ Program Studi Biologi, Fakultas MIPA, Universitas Sam Ratulangi \\ Jl. Kampus UNSRAT FMIPA, Manado 95115 \\ e-mail: fitrielizabeth19@gmail.com: fmantiri@yahoo.com: rooije.rumende@yahoo.com
}

\begin{abstract}
ABSTRAK
Macaca nigra merupakan salah satu spesies yang endemik dan terancam punah di Sulawesi Utara. Eksploitasi yang berlebihan serta alih fungsi hutan menjadi ancaman bagi spesies ini di alam. Penelitian ini dilakukan untuk mengetahui variasi sekuens intraspesies $M$. nigra yang berada di Pusat Penyelamatan Satwa Tasikoki Bitung. Analisis sekuens menunjukkan terdapat perbedaan sepuluh pasang basa nukleotida pada urutan sekuens sampel dilokasi yang berbeda. Jarak genetik antara kedua sampel yaitu 0.016. Hasil perhitungan jarak genetik menunjukkan variasi genetik masih berada dalam kisaran variasi intraspesies dengan ambang batas untuk variasi intraspesies yaitu 0.015-0.025. Selain itu, variasi juga ditunjukkan pada sampel dengan kerabat dekatnya yang terdata di GenBank disebabkan karena adanya mutasi sinonim dan mutasi nonsinonim. Analisis filogenetik berdasarkan gen COI (Cytochrome Oxidase-I) menunjukkan bahwa sampel M. nigra yang digunakan dalam penelitian ini berada satu klaster dengan $M$. nigra yang ada di database dan termasuk ke dalam kelompok Silenus.
\end{abstract}

Kata kunci: Variasi sekuens intraspesies, Gen COI, Macaca nigra, analisis filogenetik.

\section{THE STUDY INTRASPECIFIC VARIATION SEQUENCES AND PHYLOGENETIC CELEBES BLACK MACAQUE (Macaca nigra) USING COI GENE}

\begin{abstract}
Macaca nigra is listed as one of the endemic species and endangered in North Sulawesi. Exploitation and forest conversion have become threats to this species in the wild. This study was conducted to determine the intraspecific sequence variation of M. nigra located in Tasikoki Wildlife Rescue Center, Bitung. Sequence analysis revealed ten nucleotides differences between these two specimens. Genetic distance for both of specimens is 0.016 . The result of genetic distance, the genetic variation between the specimens of $M$. nigra was still within the range of intraspecific variation. Distance analysis was also conducted by comparing with the close relatives of $M$. nigra based on BLAST search, which showed range from 0.015-0.025. These differences resulted in both synonymous and nonsynonymous mutation. Phylogenetic analysis using DNA sequences of COI (Cytochrome Oxidase-I) gene revealed that the two specimens of $M$. nigra claster together with $M$. nigra sequences that have been deposited in GeneBank. Moreover M. nigra is claster in the silenus group which is in accordance with previous reports.
\end{abstract}

Keywords: Intraspecific Sequence Variation, COI Gene, Macaca nigra, Phylogenetic analysis.

\section{PENDAHULUAN}

Macaca merupakan salah satu dari Genus Primata yang mempunyai penyebaran sangat luas. Ada sekitar 20 jenis yang tersebar mulai dari gurun pasir di Afrika, hutan tropis Asia, hingga pegunungan salju di Jepang (Supriatna dan Wahyono, 2000). Macaca nigra termasuk diantara monyet Sulawesi yang terbesar. Hewan ini adalah salah satu jenis satwa liar Ordo Primata yang tergolong langka dan endemik di Sulawesi Utara (Whitten et al., 1987). Kebanyakan M. nigra ditemukan di dalam daerah yang dilindungi (kawasan lindung). Dalam daftar yang dikeluarkan IUCN, $M$. nigra digolongkan sebagai satwa hampir punah (Endangered) dan dicantumkan dalam Apendix II CITES (Supriatna dan Wahyono, 2000). 
Keberadaan $M$. nigra semakin berkurang dan terancam punah disebabkan oleh berbagai alasan, diantaranya yaitu lewat perburuan, perdagangan, pemberantasan hama pertanian, pemeliharaan di kandang, dan lain sebagainya. Populasi kecil lebih rentan pada sejumlah efek genetik yang merugikan, sehingga hewan tersebut mengalami penurunan kemampuan berevolusi atau adaptasinya pada lingkungan yang berubah. Konservasi keragaman genetik dalam suatu populasi merupakan salah satu cara untuk tetap mempertahankan keberadaan suatu populasi di alam. Suatu populasi dapat beradaptasi dengan baik terhadap perubahan yang terjadi di lingkungan sekitar disebabkan oleh adanya keragaman genetik. Keragaman genetik turut menentukan keberhasilan konservasi populasi. Oleh karena itu, usaha-usaha konservasi perlu dilakukan untuk pencegahan kepunahan yang lebih cepat pada $M$. nigra.

Filogenetik adalah studi tentang hubungan antara organisme berdasarkan kekerabatan satu sama lain, penelusuran hubungan evolusi, sejarah kehidupan suatu spesies (Brown, 2002). Analisis dilakukan untuk menduga atau mengestimasi hubungan evolusioner. Pendugaan sejarah evolusioner berdasarkan analisis filogenetik yang dilakukan biasanya digambarkan dalam diagram yang menyerupai pohon bercabang. Salah satu gen mitokondria yang dapat digunakan untuk membantu konstruksi dari pohon filogeni adalah dengan menggunakan gen COI (Cytochrome c oxidase I) yang bertindak sebagai gen marker ( $\mathrm{Li}$ et al., 2011). Penelitian ini dilakukan dengan tujuan menganalisis variasi sekuens intraspesies gen COI dan mengkonstruksi pohon filogenetik $M$. nigra dengan kerabat dekatnya di GenBank.

\section{METODE PENELITIAN}

\section{Ekstraksi DNA}

Proses ekstraksi DNA dilakukan menggunakan metode spin-column based dengan menggunakan Axyprep Multisource Genomic DNA miniprep kit (Axygen) yang dimodifikasi berdasarkan Kolondam (2012). DNA mitokondria diekstrak dari darah $M$. nigra yang diperoleh dari Pusat
Penyelamatan Satwa Tasikoki (PPST) Bitung. Penelitian dilaksanakan pada September hingga Desember 2016.

\section{Amplifikasi Gen COI dengan Metode PCR dan Sekuensing}

Primer Gen COI universal yang digunakan adalah LCO1490 (5'-GGT CAA CAA ATC ATA AAG ATA TTG G-3') dan HCO2198 (5'-TAA ACT TCA GGG TGA CCA AAA AAT CA-3') (Folmer et al., 1994). Amplifikasi gen COI dilakukan di dalam $40 \mu \mathrm{L}$ reaksi PCR menggunakan $2 \mathrm{x}$ KapaTaq PCR MasterMix. Komponen yang dicampur yaitu $20 \mu \mathrm{L} 2 \mathrm{X}$ KapaTaq, $1,5 \mu \mathrm{L}$ primer forward, $1,5 \mu \mathrm{L}$ primer reverse, $2 \mu \mathrm{L}$ templat DNA, dan $15 \mu \mathrm{L} \quad \mathrm{ddH}_{2} \mathrm{O}$ (air terdeionisasi) untuk satu kali reaksi. Pengaturan suhu untuk mesin PCR TPersonal (Bimetra) dimulai dengan denaturasi awal (initial denaturation) pada suhu $95^{\circ} \mathrm{C}$ selama 3 menit yang kemudian dilanjutkan dengan 35 siklus yang terdiri atas tahap denaturasi $\left(95^{\circ} \mathrm{C}, 30\right.$ detik), penempelan primer $\left(50^{\circ} \mathrm{C}, 40\right.$ detik $)$, dan ekstensi DNA $\left(72^{\circ} \mathrm{C}, 50\right.$ detik) seperti yang telah dilakukan oleh Kolondam (2015). Produk PCR dikirim bersama pasangan primernya untuk proses sekuensing. Semua proses termasuk PCR clean up (ekstraksi DNA dari gel) dilakukan oleh penyedia jasa sekuensing $1^{\text {st }}$ BASE Malaysia. Sekuensing dilakukan dua kali dari arah yang berbeda, sesuai dengan primer yang tersedia.

\section{ANALISIS DATA}

Hasil sekuensing yang diperoleh dari perusahaan penyedia jasa sekuensing $I^{s t}$ BASE Malaysia berupa kromatogram DNA disunting menggunakan Geneious v5.6 (Drummond et al., 2012). DNA bagian awal dan akhir dihapus sepanjang kurang lebih $30 \mathrm{bp}$. Proses reverse and complement dilakukan untuk hasil sekuensing yang menggunakan primer reserve, kemudian dipadukan dengan hasil sekuensing primer forward menggunakan MUSCLE (Multiple Sequence Comparison by Log-Expectation) yang terintegrasi dalam Geneious (Kolondam, 2015). Sekuens kemudian diubah dalam bentuk format FASTA (Fast Alignment) untuk dibandingkan dengan sekuens kerabat terdekat yang diambil dari GenBank (www.ncbi.nlm.nih.gov). 
Penjajaran sekuens DNA dan semua gap menggunakan multalin V.5.4.1 (http://multalin.toulouse.inra.fr/multalin/) yang dikembangkan oleh Corpet (1998). Pembentukan pohon filogenetik dibuat berdasarkan BOLD System dan untuk perhitungan jarak genetik digunakan metode Kimura's 2-parameter pada MEGA7 yang dikembangkan oleh Tamura et al. (2013) (Kairupan, 2015).

\section{HASIL DAN PEMBAHASAN}

Pasangan primer LCO1490 dan $\mathrm{HCO} 2198$ yang digunakan berhasil mengamplifikasi ke-4 sampel $M$. nigra yang digunakan dalam penelitian ini, tetapi dari ke-4 sampel hanya terdapat 2 sampel yang menunjukkan hasil yang baik yaitu DNA sampel FE3 dan FE4. Sampel DNA yang berhasil diamplifikasi memperlihatkan hasil pola pita yang terlihat jelas, sedangkan untuk sampel DNA FE1 dan FE2 memperlihatkan hasil pola pita yang samar dikarenakan konsentrasi yang tidak memadai sehingga tidak bisa dilakukan analisis selanjutnya. Profil DNA hasil amplifikasi gen COI disajikan pada Gambar 1.

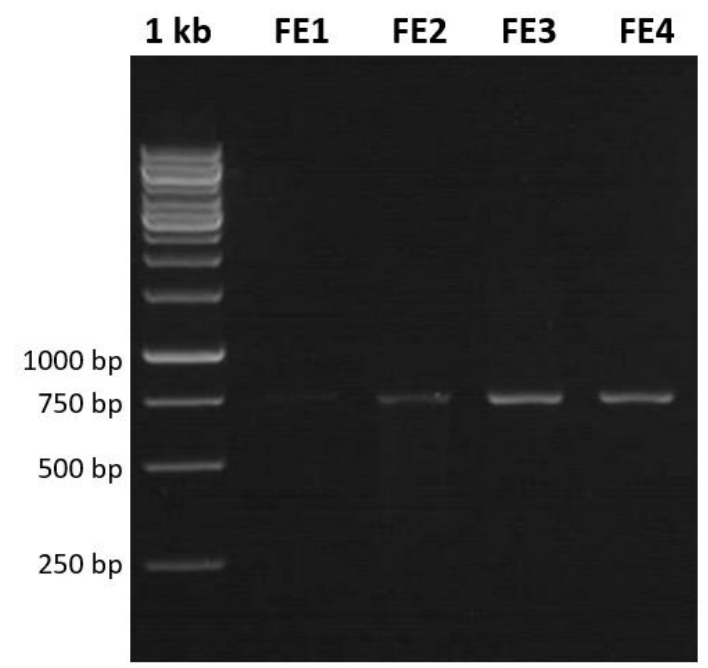

Gambar 1. Visualisasi hasil amplifikasi fragmen gen COI dari sampel M. nigra.

DNA ladder $1 \mathrm{~kb}$ dibuat sebagai pembanding sehingga dapat diketahui panjang fragmen DNA sampel yang teramplifikasi. Panjang gen COI dari ketiga sampel $M$. nigra yang berhasil diamplifikasi berada pada ukuran mendekati pita $750 \mathrm{bp}$ daripada 500 bp. Hal ini sesuai dengan perkiraan panjang pita DNA yang teramplifikasi melalui PCR yaitu sepanjang 709 bp.

Multiple alignment dua sekuens sampel M. nigra dikerjakan dengan menggunakan Geneious v5.6.4. Proses penyuntingan sekuens fragmen DNA ini dimulai dengan penghapusan urutan DNA pada bagian ujung. Tujuan dari penghapusan urutan sekuens awal adalah untuk mendapatkan bagian inti (core region), keakuratan yang sesuai dalam pengolahan data, memudahkan penjajaran dan mengurangi resiko salah pembacaan ketika pembuatan pohon filogenetik. Panjang ratarata pita yang teramplifikasi pada kedua sampel adalah $709 \mathrm{bp}$, setelah proses penghapusan, didapatkan daerah inti sekuens DNA sampel dengan panjang $631 \mathrm{bp}$. Penjajaran sekuens dilakukan dengan Multalin v5.4.1.

Hasil penjajaran kedua sampel $M$. nigra dengan menggunakan Multalin v5.4.1 (Corpet, 1988), menunjukkan adanya variasi intraspesies pada kedua sampel $M$. nigra (Gambar 2). Variasi basa nukleotida terdapat 10 titik pada gen COI yang berada pada urutan basa nomor 7, 58, 73, 148, 316, 358, 401, 406, 472 dan 583.

Variasi basa nukleotida yang terjadi pada situs-situs tersebut disebabkan karena adanya substitusi basa nukleotida. Perubahan basa yang terjadi berupa substitusi transisi dan transversi. Transisi adalah perubahan antar basa A (Adenin) dan G (Guanin) atau purin, atau antar basa $\mathrm{C}$ (Sitosin) dan $\mathrm{T}$ (Timin) atau pirimidin, sedangkan transversi adalah perubahan antara suatu basa purin dengan suatu basa pirimidin. Di antara substitusi ini, substitusi transisi paling banyak ditemukan daripada substitusi transversi. Hal ini disebabkan karena transisi bertukar basa nukleotida dari bentuk yang sama, sedangkan transversi pertukaran dari bentuk yang berbeda. Secara khusus, A (Adenin) dan G (Guanin) memiliki dua cincin, sementara C (Sitosin) dan $\mathrm{T}$ (Timin) memiliki satu cincin. Substitusi transisi ditemukan sebanyak sepuluh titik pada basa nukleotida sedangkan substitusi transversi hanya terdapat satu. Cracraft dan HelmBychowski (1991) menyatakan bahwa kecepatan transisi pada mtDNA vertebrata lebih tinggi daripada transversi, dan adanya perubahan komposisi basa atau substitusi 
pada kodon posisi ketiga lebih umum terjadi dibandingkan posisi pertama dan kedua.

Pembacaan urutan nukleotida frame 2 menunjukkan tidak ada perbedaan asam amino yang dikode. Peristiwa ini disebut mutasi sinonim yaitu mutasi pada basa nukleotida tetapi tidak menyebabkan terjadinya perubahan asam amino. Mutasi ini menghasilkan asam amino yang sama meskipun terdapat variasi basa nukleotida pada urutan sekuens (Widodo et al., 2003). Kandungan GC digunakan untuk menentukan bahwa sekuens COI dalam penelitian merupakan DNA mitokondria (mtDNA) bukan pseudogen. Geneious v5.6.4 menampilkan hasil dari kandungan GC untuk sampel FE yaitu 46,1\%, sementara untuk sampel FE4 yaitu $45,0 \%$.

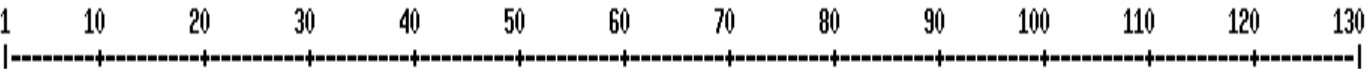

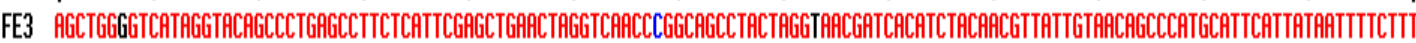

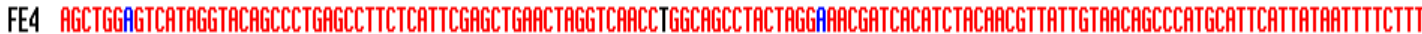

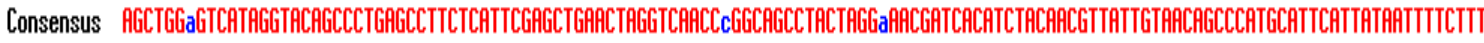

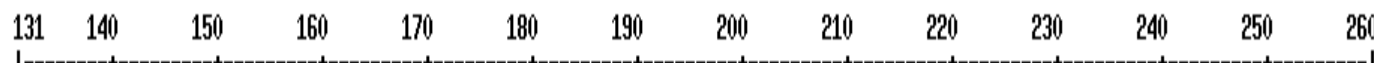

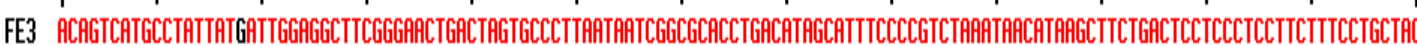

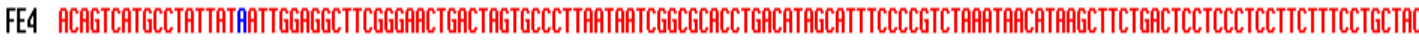

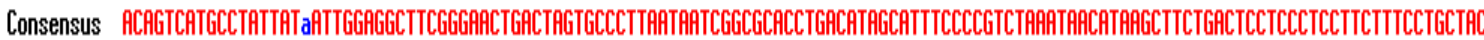

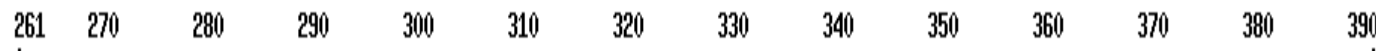

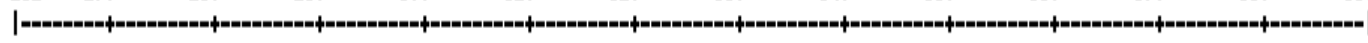

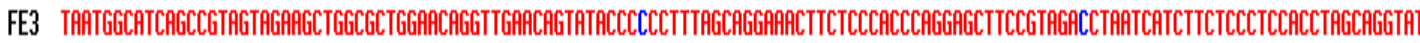

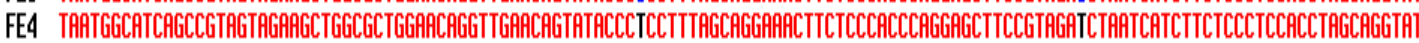

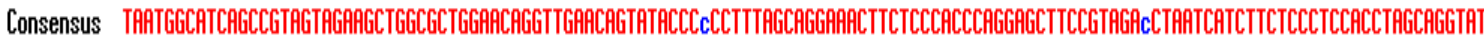

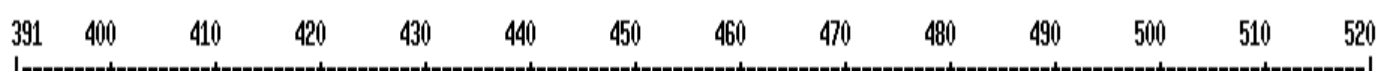

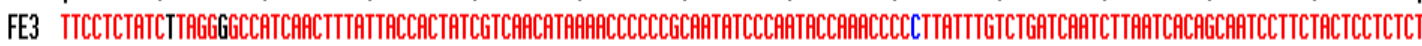

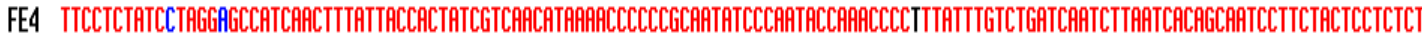
Consensus TтССТС

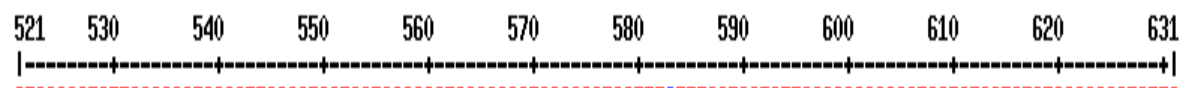

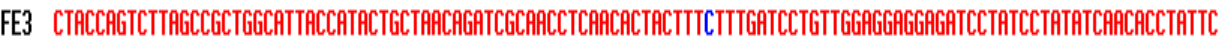

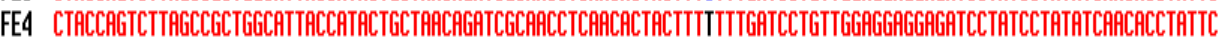

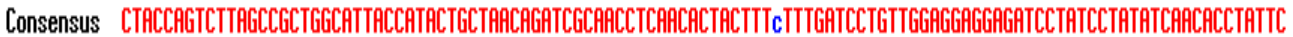

Gambar 2. Hasil penjajaran sekuens menggunakan Multalin v5.4.1.

Kandungan GC pada vertebrata 4045\% (Sueoka, 1962). Kandungan GC untuk mamalia berkisar diantara 35\%-60\% untuk genom, akan tetapi Vanyushin dan Kirnos (1977) mengungkapkan bahwa konsentrasi kandungan GC yang ada di DNA mitokondria (mtDNA) dengan DNA inti (nDNA) tidak berbeda nyata. Oleh karena itu, nilai kisaran kandungan GC untuk genom mamalia dapat digunakan sebagai acuan. Dengan demikian menandakan bahwa sekuens COI dalam penelitian ini merupakan mtDNA, bukan pseudogen. 


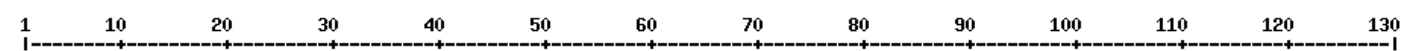

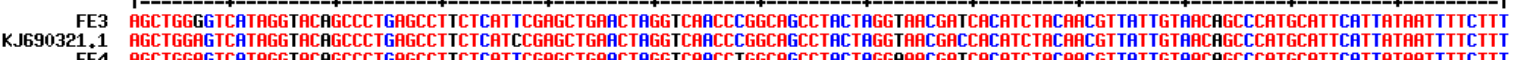

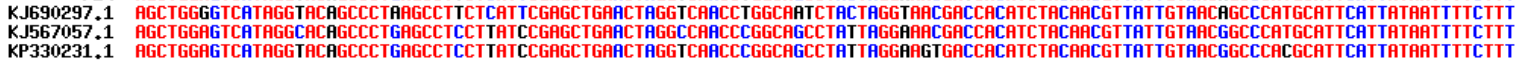
KJ567058.1 AGCTGGAGTCATAGGCACAGCCCTGAGCC TCCTCATTCGAGCTGAACTGGGCCAACCCGGCAGCC TACTAGGAAATGATCACATCTACAACGTTATTGTAACAGCCCATGCATTCATTHTAATTITCTTC KJ567056.1 AGCTGGAGTCATAGGCACCGCCCTGAGCCTTCTCATTCGAGCTGAACTAGGCCAACCGGCAACC TAT TAGGCAACGACCACATCTACAACGTTGTTGTAACGGCCCATGCTTTCATTATARTCTTCTIT KU564271 1 AGCTGGAGTCATAGGCACTGCCCTGAGCCTTCTCATTCGAGCTGAACTAGGCCAACCCGGCAGCCTATTAGGCAACGACCACATCTACAACGTTATTGTAACGGCTCATGCATTCATTRTABTCTTCTIT

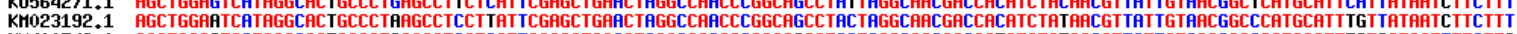

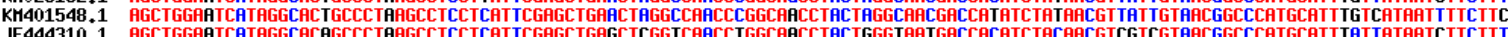
年 Consensus AGCTGG
160
170
$180 \quad 190$
200
210
$220 \quad 230$
$240 \quad 250$

260

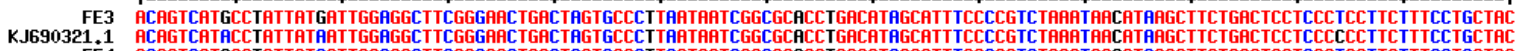
FE4 KJ690297.1 ATAGTCATACC TATTATAATTGGAGGCTTCGGGAACTGACTAGTGCCCTTAATAATCGGCGCACCCGACATAGCATTTCCCCGTCTAAATAAT HTAAGCTTCTGACTCC TCCCCCCTTCTTTCC TACTAC KJ567057.1 ACAGTCATACCCATTATGATTGGGGGCTTCGGGAPTTGATTAGTACCCTTGATAPTCGGCGCACCCGACATGGCATTTCCCCGCCTAAPTAACATAAGCTTCTGACTCCTCCCTCCTTCTTTCTTGCTAC

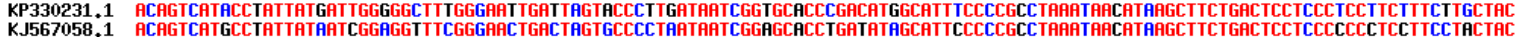
KJ567056.1

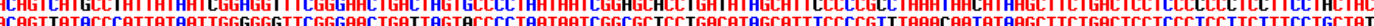

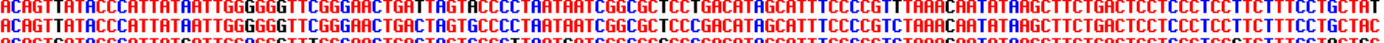

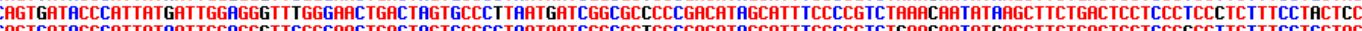

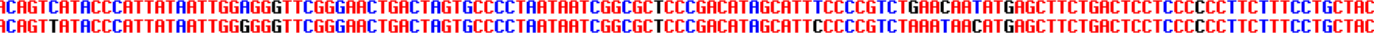

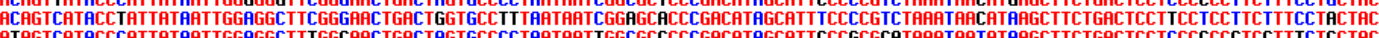

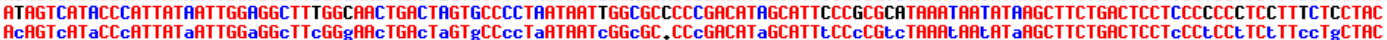

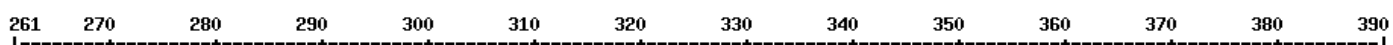

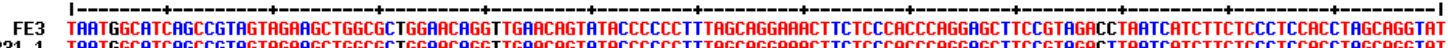
KJ690321.1 TAATGGCATCAGCCGTAGTAGAAGCTGGCGCTGGAACAGGTTGAACAGTATACCCCCCTTTAGCAGGAAACTTCTCCCACCCAGGAGCTTCCGTAGACTTHATCATCTTCTCCCTCCACCTAGCAGGTAT KJ690297.

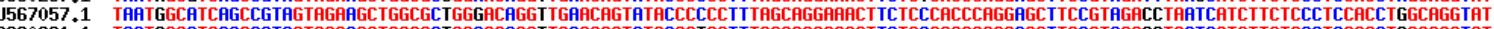
WP330231.1 TAATGGCATCAGCCGTAGTAGAAGCTGGCGCTGGAACAGGTTGAACAGTATACCCTCCTITAGCAGGAACTTCTCCCACCCAGGAGCTTCCGTAGACCTAATCATCTTCTCCCTCCACCTGGCAGGTHT KJ567058.1 TAATAGCATCAGCCGTAGTAGAAGCTGGCGCCGGAACAGGCTGAACAGTATACCCCCCTCTAGCAGGAAPTTTCTCCCACCCAGGAGCTTCTGTAGATTTAGTTATCTTCTCCCTCCACCTAGCAGGTAT

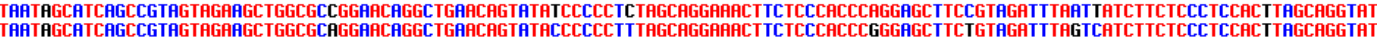

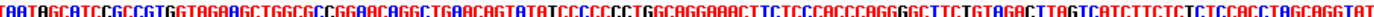

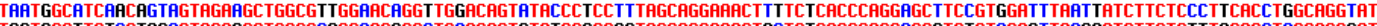
TGCTCGCTTCTGCThCAg

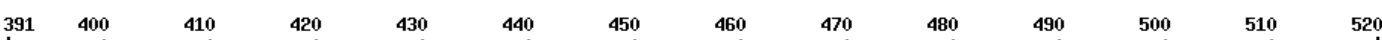

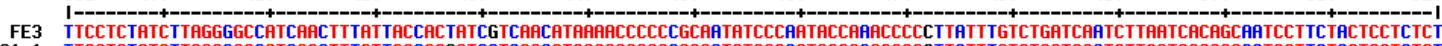

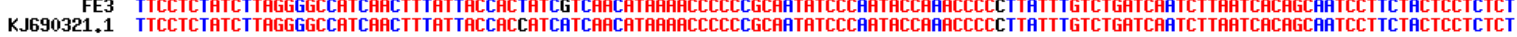

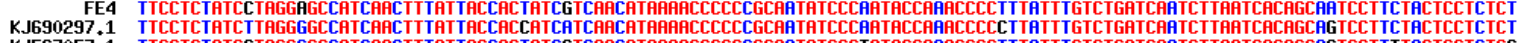

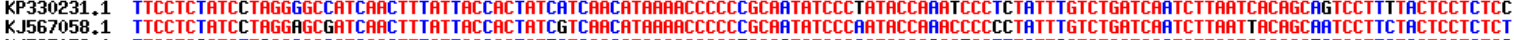
KJ567056.1 ITCC TCCATCTTGGGGGCCATCAACTTTATTACCACTATTATCAACATAAAACCCCC TGCACTATCCCAATACCAGACTCCTTTATTCGTCTGATCAATCTTAATCACAGC TATCCTTCTACTCC TCTCC

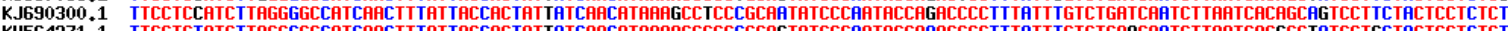
KH023192.1 KH401548 1 TTCTCT⿱宀八

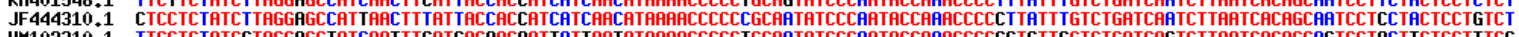

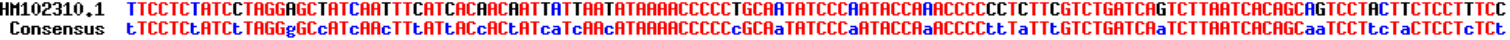
$570 \quad 58$
610
620
631

FE3 CTACCAGTCTTAGCCGCTGGCATTACCATACTGCTAACAGATCGCAACCTCAACACTACTITCTTTGATCCTGTTGGAGGAGGAGATCCTATCCTATATCAACACCTRTTC

KJ690321.1 CTACCAGTCTTAGCCGCTGGCATTACCATACTGC TAACAGATCGCAACC TCAACACTACTTTCTTTGATCCTGTTGGGGGAGGAGATCC TATCC TATATCAACACC TATTT

KJ690297.1 CTACCAGTCTTAGCCGCTGGCATTACCATACTGCTAACAGATCGCAACCTCAACACTACTTTCTITGATCCTGTTGGGGGAGGAGATCCTATCCTATHTCAACACCTATTT

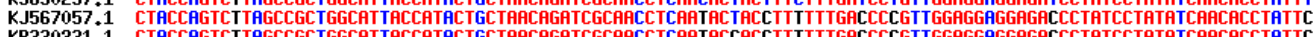

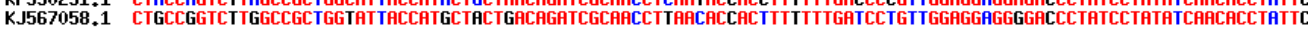

KJ567056.1 CTACCGGTCTTAGCTGCTGGCATTACCATACTGCTHACAGATCGCAATCTCAATACTACCTTCTITGACCCTGTTGGAGGAGGAGACCCTATCCTATACCAACACC TATTT

KJ690300.1 CTACCAGTCCTAGCCGCCGGCATTACCATATTACTAACAGATCGCAACCTCHATACTACCTTCTITGATCCTGTTGGAGGGGGAGATCC TRTCCTATATCCACACC TATTT

KU564271.1 CTACCAGTCCTACCGCCGGCACACCATGCTGCTAACA

KH023154.1 CTACCAGTCCTAGCCGCTGGCATTACCATGCTACTAACAGATCGCAACC TCAATACTACTTTCTTTGACCCTGTTGGAGGGGGAGATCCTATCCTATATCAACACC TATTT

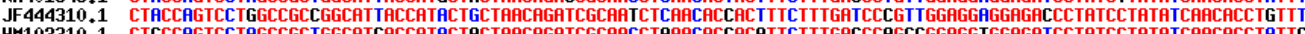

HM102310.11
CTCCCAGTCCTAGCCGCTGGCATCACCATACTACTAACAGATCGCAACCTAARCACCACATTCTITGGCCCAGCCGGAGGTGGAGATCCTATCCTATATCAACACCTATTC
Consensus

Gambar 3. Hasil Penjajaran sekuens $M$. nigra dengan keraat dekatnya menggunakan program Multalin v5.4.1 


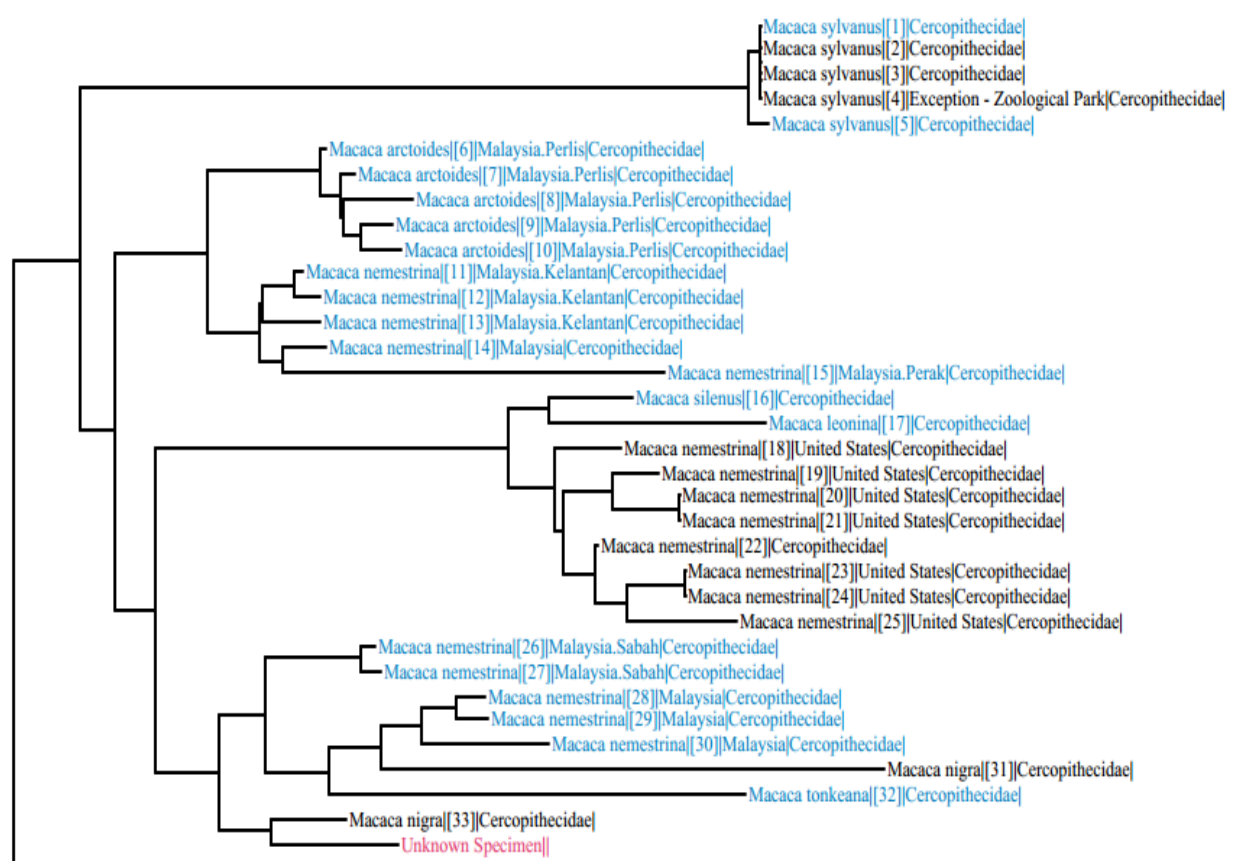

Gambar 4a. Pohon filogeni sampel M. nigra FE4 yang dikonstruksi dengan BOLD TaxonID Tree. Keterangan: Unknown specimen $=$ Sampel FE4.

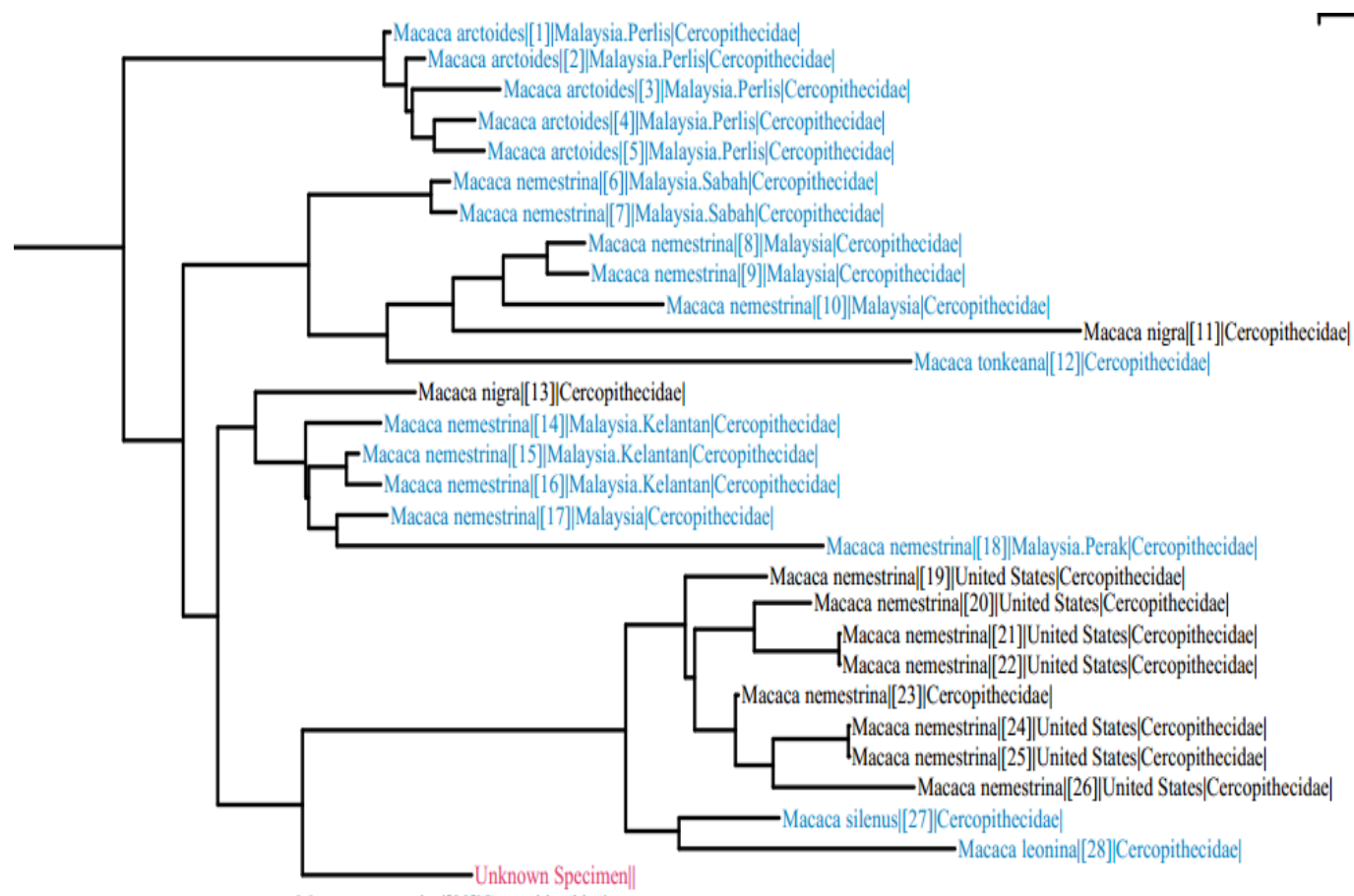

Gambar 4b. Pohon filogeni sampel M. nigra FE3 yang dikonstruksi dengan BOLD TaxonID Tree Keterangan: Unknown specimen $=$ Sampel FE3

Sekuens fragmen DNA yang telah disunting diubah ke dalam bentuk FASTA untuk dibandingkan dengan sekuens kerabat terdekatnya dari GenBank menggunakan metode BLAST. Dua belas sampel kerabat dekatnya yang diambil di GenBank 
kemudian dibuat penjajaran sekuensnya menggunakan Multalin v5.4.1 (Gambar 3).

Hasil penjajaran sampel dengan kerabat dekatnya memperlihatkan banyak variasi pada basa nukleotida. Pembacaan urutan nukleotida dengan menggunakan frame 2 menunjukkan terdapat banyak variasi asam amino yang dikode, ditemukan 21 situs yang disebabkan oleh mutasi nonsinonim dan yang lainnya mutasi sinonim. Mutasi nonsinonim adalah mutasi yang menyebabkan terjadinya perubahan asam amino. Variasi yang terjadi pada basa nukleotida disebabkan oleh adanya mutasi. Mutasi menjadi penyebab utama perbedaan variasi basa nukleotida pada gen COI. Variasi yang kecil dapat mempengaruhi keidentikan suatu spesies dan bahkan dapat mempengaruhi susunan asam amino yang mengkodekan protein (Mattern et al, 2009).

Pohon filogeni dikonstruksi menggunakan BOLD TaxonID Tree dan jarak genetik menggunakan metode Kimura2-parameter yang terintegrasi di dalam piranti lunak MEGA7. Pohon filogeni sebelumnya dikonstruksi menggunakan MEGA7 yang dikembangkan oleh Tamura et al. (2013), tetapi hasil yang didapatkan tidak sesuai dengan yang diharapkan karena sekuens $M$. nigra yang ada di database tidak berada dalam satu klaster dengan sampel $M$. nigra dalam penelitian ini. Pohon filogeni yang dikonstruksi dengan BOLD TaxonID Tree ini menunjukkan hasil sekuens sampel $M$. nigra berada dalam satu klaster dengan sekuens $M$. nigra yang ada di database. Pohon filogeni disajikan pada Gambar 4.

Kladogram menunjukkan bahwa sampel $M$. nigra FE3 dan FE4 masih berada dalam satu klaster dengan $M$. nigra yang ada di database. Unknown specimen pada kladogram (Gambar 4a dan Gambar 4b) merupakan sampel $M$. nigra yang digunakan dalam penelitian. Sampel M. nigra termasuk ke dalam kelompok Silenus. Anggota dari klaster ini sebagian besar merupakan Macaca Sulawesi. Hasil penelitian Li et al. (2009), mengungkapkan bahwa genus Macaca terbagi atas empat kelompok monofiletik yaitu kelompok Sinica, Sylvanus, Silenus dan Fascicularis. Macaca Asia termasuk kedalam kelompok Silenus, dimana kelompok Silenus ini memiliki anggota $M$. nigra, $M$. silenus dan $M$. nemestrina. Hasil penelitian menunjukkan bahwa $M$. nigra paling berkerabat dekat dengan $M$. nemestrina. Evans et al. (1999), mengungkapkan bahwa beberapa halotipe dari $M$. nemestrina memiliki hubungan kekerabatan dengan Macaca yang berasal dari Sulawesi bagian utara hingga Sulawesi bagian tengah dan sebagian lagi memiliki hubungan kekerabatan dengan Macaca yang berada di Sulawesi bagian selatan, sehingga memungkinkan jika $M$. nigra dan $M$. nemestrina masih berada dalam satu klaster monofiletik di pohon filogeni.

Jarak genetik dihitung menggunakan

metode Kimura-2-parameter yang terintegrasi di dalam piranti lunak MEGA7. Analisis jarak genetik merupakan analisis berdasarkan penghitungan matriks dari "jarak" antar pasangan basa antara sekuens yang mendekati jarak evolusioner (Dowell, 2005). Jarak genetik dari masing-masing sampel pada pohon filogenetik disajikan pada Tabel 1.

Tabel 1. Jarak genetik sampel M. nigra dengan kerabat dekatnya menggunakan analisis Kimura-2-parameter dalam MEGA7

\section{FE3}

\begin{tabular}{lllllllll}
\hline FE4 & 0.016 & & & & & & \\
\hline JF444310.1_Macaca_sylvanus & 0.095 & 0.091 & & & & & \\
\hline KJ567057.1_Macaca_silenus & 0.059 & 0.059 & 0.124 & & & & \\
\hline KJ567058.1_Macaca_tonkeana & 0.077 & 0.069 & 0.122 & 0.101 & & & \\
\hline KJ690297.1_Macaca_arctoides & 0.038 & 0.045 & 0.086 & 0.086 & 0.105 & & \\
\hline KJ690321.1_Macaca_nemestrina & 0.016 & 0.026 & 0.084 & 0.062 & 0.084 & 0.028 & \\
\hline KP330231.1_Macaca_leonina & 0.069 & 0.066 & 0.122 & 0.023 & 0.111 & 0.094 & 0.069 \\
\hline
\end{tabular}


Jarak genetik antara sampel FE3 dan FE4 yaitu 0.016, nilai jarak ini menunjukkan adanya variasi intraspesies. Kisaran nilai jarak genetik untuk membedakan intraspesies pada mamalia menurut Tobe et al. (2010) yaitu antara 0,015-0,025. Nilai jarak genetik FE3 dan FE4 masih tergolong dalam kisaran variasi intraspesies. Semakin besar nilai jarak genetik ( $p$-distance) diantara suatu populasi atau individu, semakin terisolasi antara satu dengan lainnya. Jarak genetik menunjukkan kemungkinan adanya pengaruh isolasi geografis terhadap suatu populasi (Schmitt dan Haubrich, 2008). Analisis berdasarkan jarak genetik menunjukkan bahwa sampel FE3 dan FE4 yang menjadi sampel dalam penelitian ini termasuk spesies yang sama yaitu $M$. nigra memiliki perbedaan jarak genetik dengan nilai $1,6 \%$ artinya terdapat variasi intraspesies pada sampel yang disebabkan karena adanya mutasi.

Nilai jarak genetik untuk sampel FE3 dan FE4 sama dengan jarak genetik untuk sampel FE3 dan M. nemestrina. Nilai jarak genetik antara FE3-FE4 dan FE3- $M$. nemestrina yaitu 0,016 artinya rata-rata jarak genetik secara keseluruhan sebesar 1,6\% menunjukkan bahwa dari panjang sekuens 631 bp hanya ada 10 nukleotida yang berbeda. Posisi perbedaan basa nukleotida itu berbeda dalam sekuens meskipun jarak genetik antara FE3-FE4 dan FE3- $M$. nemestrina memiliki nilai yang sama.

\section{KESIMPULAN}

1. Sekuens gen COI sampel Macaca nigra FE3 dan FE4 menunjukkan adanya variasi intraspesies. Variasi ditunjukkan dengan adanya perbedaan 10 pasang basa nukleotida pada urutan sekuens sampel dilokasi yang berbeda.

2. Macaca nigra sampel penelitian berada satu klaster dengan Macaca nigra yang terdapat di database dan termasuk kedalam kelompok Silenus.

\section{DAFTAR PUSTAKA}

Brown, T.A. 2002. Genomes $2^{\text {nd }}$. Magdalen Road, Oxford, UK: BIOS Scientifict Publisher Ltd.
Corpet, F. 1998. Multiple Sequence Alignment with Hierarchical Clustering. NUCL. Acids res. 16(22): 10881-10890.

Cracraft, J. and K. Helm-Bychowski. 1991. Parsimony and Phylogenetic Inference Using DNA Sequences: Some Methodological Strategies. In Phylogenetic Analysis of DNA Sequences. M. Miyanmoto and J. Cracraft (Eds.). Oxford Univ. Press, New York.

Dowell, K. 2005. Molecular Phylogenetics an Introduction to Computational Methods and Tools for Analyzing Evolutionary Relationships. Math 500: 1-19.

Drummond, A.J., B. Ashton., S. Buxton., M. Cheung., A. Cooper., C. Duran., M. Field., J. Heled., M. Kearse., S. Markiwitz., R. Moir., S. StonesHavas., S. Sturrock., T. Thierer., dan A. Wilson. 2012. Geneious v5.6. Biomatters. New Zealand.

Evans, B.J., J.C, Morales., J. Supriatna dan D.J, Melnick. 1999. Origin of the Sulawesi macaques (Cercopithecidae: Macaca) as suggested by mitochondrial DNA phylogeny. Biological Journal of the Linnean Society 66:539-560.

Folmer, O., M. Black., W. Hoeh., R. Lutz dan R. Vrijenhoek. 1994. DNA primers

for amplification of mitochondrial cytochrome c oxidase subunit I from diverse metazoan invertebrates. Molecular Marine Biology and Biotechnology 3(5): 294-299.

Kairupan, C.F. 2015. Variasi Genetik Troides Helena (Lepidoptera: Papilionidae) Berdasarkan Gen COI (Cytochrome C Oxidase) [Skripsi]. Jurusan Biologi UNSRAT Manado.

Kolondam, B.J. 2012. Barcode DNA rbcl dan matK Aglaonema (Aglaonema sp.), Anthurium Gelombang Cinta (Anthurium plowmanii) dan Anggrek Payus Limondok (Phaius tancarvilleae) [tesis]. Program Pascasarjana UNSRAT Manado. 
Kolondam, B.J. 2015. Applying matK gene for identification of liliopsida plant species from North Sulawesi through Bold System. International Journal of Applied Biology and Pharmaceutical Technology. 6 (2): 242-245.

Li, J., K. Han., J. Xing., K. Heui-Soo., J. Rogers., O.A Ryder., T. Disotell., B. Yue dan M.A, Batzer. 2009. Phylogeny of the Macaques (Cercopithecidae: Macaca) Based on Alu Elements. Gene 15:448(2): 242249.

Li, C., M. Wang, F. Cheng, dan S. Sun. 2011. DNA Barcoding and Its Application to Marine Zooplankton Ecology. Biodiv. Sci. 19(06): 805-814.

Mattern, A., Desender, K., Drees, C., Gaublomme, E., Paill, W., dan Assmann, T. 2009. Genetic Diversity and Population Structure of thr Endangered Insect Species Carabus variolosus in its Western Distribution Range: Implications for Concervation. Concerv Genet.

Schmidt, H. 2003. Phylogenetic Trees from Large Datasets. InauguralDissertation, Dusseldorf University.

Sueoka, N. 1962. On the Genetic Basis of Variation and Heterogeneity of DNA Base Composition. Genetics 48: 589592.

Supriatna, J., dan E.H Wahyono. 2000. Panduan Lapangan Primata Indonesia. Yayasan Obor Indonesia. Jakarta.

Tamura, K., Stecher, G., Peterson, D., Filipski, A., Kumar, S. 2013. MEGA7: Molecular Evolutionary Genetics Analysis Version 7.0. Molecular Biologi and Evolution 30(12): 27252729.

Tobe, S.S., A.C, Kitchener dan A.M.T, Linacre. 2010. Reconstruction Mammalian Phylogenies: A Detailed Comparison of the Cythochrome $b$ and Cythochrome Oxidase Subunit I Mitochondrial Genes. PLOS One Journals.
Vanyushin, B.F dan Kirnos. 1977. The Structure of Animal Mitochondrial DNA (Base Composition, Pyrimidine Clusters, Character of Methylation). Mol Cell Biochem 14(1-3): 31-36.

Whitten, A.J., M. Mustafa dan J.B. Henderson. 1987. Ekologi Sulawesi. Gadjah Mada University Press. Yogyakarta.

Widodo, A., L, Mohammad dan Umie. 2003. Evolusi. Malang: UM Press. 